\title{
Histone deacetylase inhibitors differentially stabilize acetylated p53 and induce cell cycle arrest or apoptosis in prostate cancer cells
}

\author{
S Roy ${ }^{1}$, K Packman ${ }^{1}$, R Jeffrey ${ }^{1}$ and M Tenniswood ${ }^{\star, 1}$ \\ 1 Department of Biological Sciences, University of Notre Dame, Notre Dame, \\ IN 46556, USA \\ * Corresponding author: M Tenniswood, Department of Biological Sciences, \\ University of Notre Dame, Notre Dame, IN 46556, USA. \\ Tel: + 1-574-631-3372; Fax: + 1-574-631-7413; \\ E-mail: Tenniswood.1@nd.edu
}

Received 12.5.04; revised 17.12.04; accepted 17.12.04; published online 04.3.05 Edited by V De Laurenzi

\begin{abstract} a p53-independent mechanism.

Cell Death and Differentiation (2005) 12, 482-491.

doi:10.1038/sj.cdd. 4401581

Published online 4 March 2005
\end{abstract}

In LNCaP prostate cancer cells CG-1521, a new inhibitor of histone deacetylases, alters the acetylation of p53 in a sitespecific manner. While p53 is constitutively acetylated at Lys320 in LNCaP cells, treatment with CG-1521, stabilizes the acetylation of p53 at Lys373, elevating p21 (and inducing cell cycle arrest). Treatment with CG-1521 also promotes Bax translocation to the mitochondria and cleavage, and apoptosis. TSA stabilizes the acetylation of p53 at Lys382, elevating p21 levels and inducing cell cycle arrest, but does not induce Bax translocation or apoptosis. In LNCaP cells CG-1521, but not TSA, promotes the rapid degradation of HDAC2. These data suggest that the acetylation of $p 53$ at Lys 373 is required for the p53-mediated induction of cell cycle arrest and apoptosis, while acetylation of $p 53$ at Lys 382 induces only cell cycle arrest. In $\mathrm{p}^{-1-}$ PC3 cells both compounds induce $\mathrm{p} 21$ and cell cycle arrest, but not Bax translocation or apoptosis, suggesting that both compounds can also induce p21 through

Keywords: acetylation; Bax; HDAC; p21

Abbreviations: HDAC, histone deacaetylase; HAT, histone acetyltransferase; TSA, trichostatin A; SAHA, suberoylanilide hydroxamic acid; CG-1521, 7-phenyl-2,4, 6-hepta-trienoic hydroxamic acid

\section{Introduction}

Histone deacetylases (HDACs) represent a family of enzymes that cooperate with histone acetyltransferases (HATs) to modulate chromatin structure and transcriptional activity via changes in the acetylation status of nucleosomal histones. ${ }^{1}$ While histones $\mathrm{H} 2 \mathrm{~A}, \mathrm{H} 2 \mathrm{~B}, \mathrm{H} 3$ and $\mathrm{H} 4$ all exhibit acetylated, $\varepsilon$-amino-terminal lysine residues within the tails extending from the histone octamer of the nucleosomal core, histones $\mathrm{H} 3$ and $\mathrm{H} 4$ are the main targets of HDAC enzymatic activity. ${ }^{2-5}$ In addition to chromatin remodeling, the HDAC enzyme complex has been linked with several important regulatory pathways for growth and differentiation. HDACs regulate a variety of transcriptional pathways by forming complexes with transcriptional repressors, co-repressors and other transcriptional factors, including unliganded nuclear hormone receptors, ${ }^{6}$ SMRT, ${ }^{7} \mathrm{~N}-\mathrm{CoR},{ }^{8,9}$ retinoblastoma protein (Rb), ${ }^{10,11} \mathrm{Max} /$ $\mathrm{Mad}^{12,13}$ and Sp1. ${ }^{14}$

Mammalian HDACs have been divided into three or four subclasses. ${ }^{15}$ HDACs $1,2,3$ and 8 , which are homologous to the yeast RPD3 protein, constitute class I; HDACs 4, 5, 6, 7, 9 and 10 are related to the yeast $\mathrm{Hda} 1$ protein and form class II. Mammalian homologs of the yeast Sir2 protein have been identified, forming a third class of deacetylases referred to as sirtuins, while by phylogenetic analysis the newly identified HDAC11 represents a new class of histone acetylases. ${ }^{16}$ All of these HDACs are components of multiprotein complexes. In particular, class I and II HDACs have been shown to interact with the transcriptional co-repressors $\mathrm{mSin} 3, \mathrm{~N}-\mathrm{CoR}$ and SMRT, which recruit HDACs to transcription factors.

Since recruitment of HDACs predominantly leads to transcriptional repression, inhibitors of this enzymatic activity can reverse repression in dividing cells and lead to reexpression of genes inducing cell cycle arrest, differentiation and/or cell death. Therefore, HDAC inhibitors are being considered as candidate drugs in cancer therapy. ${ }^{16-18}$ The efficacy of these enzyme inhibitors, particularly Trichostatin $A$ (TSA), ${ }^{19-21}$ suberoylanilide hydroxamic acid (SAHA), ${ }^{22-24}$ trapoxin, ${ }^{25}$ and M-carboxycinnamic acid bishydroxamide $(\mathrm{CBHA})^{26}$ has been established by in vitro experiments, experimental therapy and ongoing clinical trials. ${ }^{18,27}$

The p53 tumor suppressor exerts antiproliferative effects, including growth arrest, apoptosis, and cell senescence, in response to various types of stress. ${ }^{28-30}$ Mutations within the p53 gene have been documented in more than half of all human tumors. Accumulating evidence further indicates that, in the cells that retain wild-type p53, other defects in the p53 pathway also play an important role in tumorigenesis. ${ }^{29}$ The molecular function of p53 that is required for tumor suppression appears to involve its ability to act as a transcriptional factor in regulating downstream target gene expression. ${ }^{31,32}$ p53 is a short-lived protein whose activity is maintained at low levels in normal cells. Tight regulation of p53 is essential for its effect on tumorigenesis as well as maintaining normal cell growth. The precise mechanism by which p53 is activated by cellular stress is not completely understood; however, it is generally accepted that this involves post-translational modifications of $p 53$, including phosphorylation and acetylation. ${ }^{33}$ Previous studies have indicated that $\mathrm{p} 300 / \mathrm{CBP}$, the histone acetyl transferase, strongly potentiates p53-dependent transcriptional activation, and that acetylation of p53 by p300 
markedly stimulates its sequence-specific DNA-binding activity and transcriptional activity. ${ }^{34-37}$ Multiple lysine (Lys) residues in p53 are acetylated. In vitro, Lys320 is acetylated by P/CAF (p300/CBP associated factor), ${ }^{36}$ while Lys373 and Lys382 are acetylated by $\mathrm{p} 300$ and CBP. ${ }^{36,37}$ In vivo studies show that some of these sites are acetylated in response to DNA-damaging agents, demonstrating that acetylation is a bona fide modification for p53. ${ }^{36}$ The proportion of acetylated p53 is increased when cells are treated with HDAC inhibitors such as $\mathrm{TSA}^{37}$ and increasing the levels of p53 acetylation with HDAC inhibitors also prevents p53 degradation in vivo, ${ }^{38}$ implying that there is tight regulation of functional p53 levels by acetylation and de-acetylation. However, despite the observation that acetylation can stimulate p53 DNA binding activity, the precise function of acetylation and the identities of the p53 deacetylases that modify these sites remain to be established.

In this report, we present evidence that a novel HDAC inhibitor, CG-1521 (7-phenyl-2,4,6-hepta-trienoic hydroxamic acid), which is structurally related to other HDAC inhibitors such as SAHA, stabilizes the acetylation of p53 at Lys373, inducing cell cycle arrest and apoptosis in LNCaP prostate cancer cells, while TSA that stabilizes the acetylation of p53 at Lys382 induces only cell cycle arrest in the cell line. The stabilization of acetylated Lys373 by CG-1521 appears to be associated with the specific degradation of HDAC2 but not HDAC1. p53 acetylated at Lys373 induces downstream activation of the cyclin-dependent kinase (CDK) inhibitor p21 and the translocation and cleavage of Bax, while TSA only induces p21.

\section{Results}

\section{CG-1521 suppresses growth and induces $G_{2} / M$ arrest in LNCaP and PC-3 cells and apoptosis in LNCaP cells in vitro}

CG-1521 has potent growth inhibitory properties in androgen receptor positive LNCaP prostate cancer cells. Crystal violet analysis shows that CG-1521 induces dose-dependent decrease in cell number, with an $\mathrm{IC}_{50}$ in the range of 5$10 \mu \mathrm{M}$ at 48 and $72 \mathrm{~h}$ after treatment (Figure 1a). This decrease is associated with both $\mathrm{G}_{2} / \mathrm{M}$ arrest and an increase in the sub-G $G_{0}$ population, which is indicative of apoptosis (Table 1). The induction of apoptosis was confirmed by terminal deoxynucleotidyl transferase mediated nick-end labeling (TUNEL) analysis (Figure 1e), which shows a dose-dependent increase in DNA fragmentation at $48 \mathrm{~h}$. In contrast, CG-1521 induces cell cycle arrest in androgen receptor negative $P C-3$ cells at $G_{2} / M$ interface with no increase in the sub- $G_{0}$ population or DNA fragmentation (Figure $1 \mathrm{~b}$, e, Table 1). Treatment of LNCaP cells or PC-3 cells with the well-known HDAC inhibitor TSA induces cell cycle arrest (Figure 1c, d) with no evidence of apoptosis (data not shown).

\section{CG-1521 induces acetylation of histone H3 and H4}

Treatment of LNCaP cells with $7.5 \mu \mathrm{M}$ CG-1521 induces hyperacetylation of both isoforms of histone $\mathrm{H} 3$ as early as $1 \mathrm{~h}$

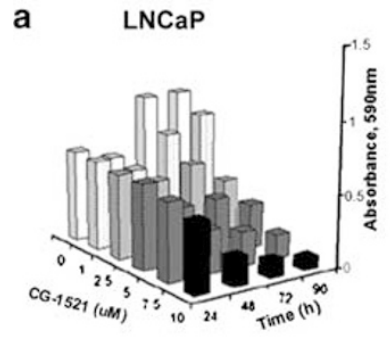

b
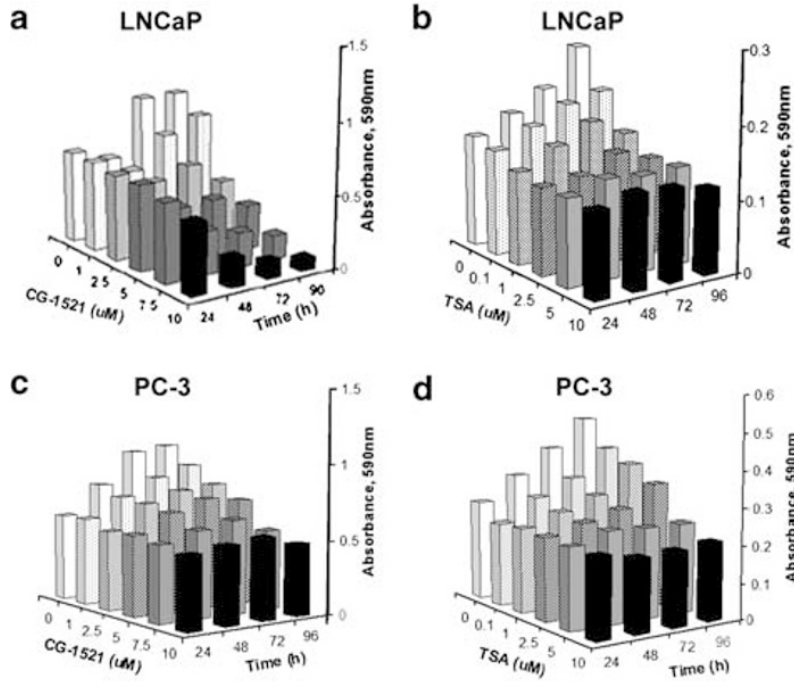

d

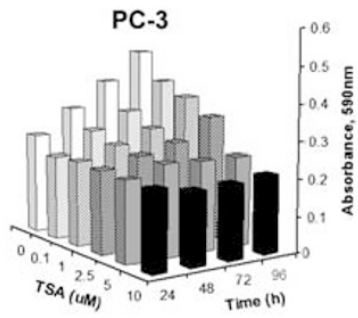

e

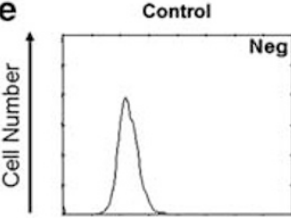

CG-1521 $5 \mu \mathrm{M}$

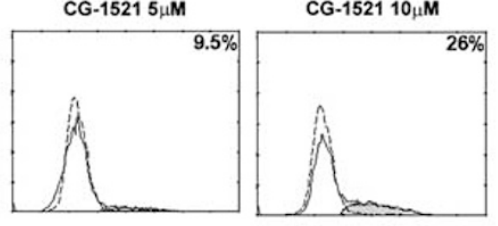

Fluorescence (BrdUTP incorporation)

Figure 1 Effect of CG-1521 and TSA on cell growth and apoptosis in LNCaP and PC-3 cells. LNCaP (a, b) and PC-3 (c, d) cells were plated in 24-well plates at $2 \times 10^{4}$ cells/well and $1 \times 10^{4}$ cells/well, respectively. At $24 \mathrm{~h}$ after plating, the cells were treated with $1 \mu \mathrm{M}$ up to $10 \mu \mathrm{M}$ CG-1521 (a, c) or 0.1-10 $\mu \mathrm{M}$ TSA (b, d) for $0-96 \mathrm{~h}$. The number of surviving, adherent cells was measured using the crystal violet assay as described in Materials and Methods. DNA fragmentation was monitored by Flow cytometric evaluation of ApoBrdU staining after treatment of LNCaP cells with 5 and $10 \mu \mathrm{M} \mathrm{CG}-1521$ (e). Results are representative of three independent experiments

Table 1 Effect of CG-1521 on cell cycle kinetics of LNCaP and PC-3 cells after $48 \mathrm{~h}$ of treatment

\begin{tabular}{|c|c|c|c|c|}
\hline \multirow[b]{2}{*}{ LNCaP } & \multicolumn{4}{|c|}{$\%$ Cell cycle } \\
\hline & Sub-G 0 & $\mathrm{G}_{0} / \mathrm{G}_{1}$ & $\mathbf{S}$ & $\mathrm{G}_{2} / \mathrm{M}$ \\
\hline Control & 0.9 & 78.0 & 13.2 & 8.8 \\
\hline CG-1521, $5 \mu \mathrm{M}$ & 7.6 & 48.8 & 10.5 & 40.6 \\
\hline CG-1521, $7.5 \mu \mathrm{M}$ & 14.7 & 56.3 & 15.6 & 28.1 \\
\hline $\mathrm{TNF} \alpha, 10 \mathrm{ng} / \mathrm{ml}$ & 3.6 & 85.8 & 8.5 & 5.7 \\
\hline PC-3 & Sub-G 0 & $\mathrm{G}_{0} / \mathrm{G}_{1}$ & S & $\mathrm{G}_{2} / \mathrm{M}$ \\
\hline Control & 0.9 & 48.3 & 16.8 & 34.0 \\
\hline CG-1521, $7.5 \mu \mathrm{M}$ & 1.0 & 19.8 & 17.9 & 61.3 \\
\hline Etoposide, $10 \mu \mathrm{M}$ & 8.4 & 26.4 & 16.7 & 48.5 \\
\hline
\end{tabular}

In LNCaP cells, CG-1521 induces a significant increase in the number of cells arrested in $G_{2} / M$ and a large increase in the sub- $G_{0}$ population. Treatment with $T N F \alpha$, which is well documented to induce $G_{0} / G_{1}$ arrest and apoptosis in $L N C a P$ cells, is shown as a positive control. In PC-3 cells, CG- 1521 causes a significant increase in the number of cells arrested in $\mathrm{G}_{2} / \mathrm{M}$ phase but no increase in the sub- $G_{0}$ population. Treatment with etoposide, which induces apoptosis in $P C-3$ cells, also induces a significant increase in the $\mathrm{G}_{2} / \mathrm{M}$ population

(Figure 2a) and is sustained up to $24 \mathrm{~h}$ treatment. Similar results are obtained with the acetylation level of histone $\mathrm{H} 4$ (Figure 2b). These data demonstrate that the effects of 

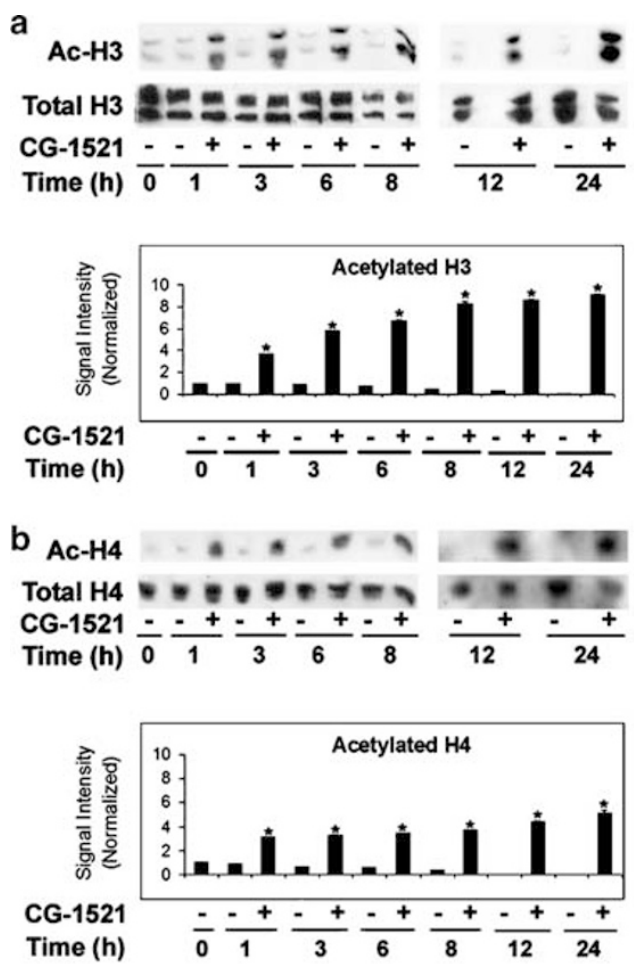

Figure 2 Effect of CG-1521 on acetylation of histone H3 and H4. LNCaP cells were treated with $7.5 \mu \mathrm{M}$ CG-1521 from 0 to $24 \mathrm{~h}$ and acid extracted for histones as described in Materials and Methods. In total, $10 \mu \mathrm{g}$ of extracted histones was loaded to AUT gels. The levels of acetylated histone $\mathrm{H} 3$ and total histone $\mathrm{H} 3$ (a) and acetylated histone $\mathrm{H} 4$ and total histone $\mathrm{H} 4$ (b) were detected by immunoblotting. The signal intensity of acetylated $\mathrm{H} 3$ and $\mathrm{H} 4$ and total $\mathrm{H} 3$ and $\mathrm{H} 4$ protein levels was measured with Kodak 1D imaging software. Due to the nature of AUT gels these blots are not normalized against a standard loading control

CG-1521 on the acetylation of histone $\mathrm{H} 3$ and $\mathrm{H} 4$ occur well before the induction of cell cycle arrest and apoptosis in LNCaP cells.

\section{CG-1521 induces acetylation of p53 and its subsequent stabilization in LNCaP $\left(\mathrm{p} 53^{+/+}\right)$cells}

Untreated LNCaP cells, which are wild type for $p 53$, contain low levels of p53 and there is no evidence of p53 acetylated at Lys373 or Lys382. Treatment with $7.5 \mu \mathrm{M}$ CG-1521 induces the stabilization of p53 acetylated at Lys373 and/or Lys382 as early as $3 \mathrm{~h}$, and the levels of acetylated p53 are maintained for at least $24 \mathrm{~h}$ (Figure 3a). This is accompanied by a statistically significant increase in the levels of total p53 after $3 \mathrm{~h}$ of treatment, which is maintained up to $24 \mathrm{~h}$ of treatment at which time the level of total p53 is five-fold higher than the endogenous level in untreated cells (Figure 3a). To determine whether the effects of CG-1521 are unique or whether the mechanism can be generalized to other HDAC inhibitors, the effects of another widely studied HDAC inhibitor, TSA on $\mathrm{LNCaP}$ cells were analyzed. TSA transiently induces acetylation of p53 at Lys373/Lys382 reaching a maximum level between 6 and $8 \mathrm{~h}$ after treatment with $5 \mu \mathrm{M}$ TSA, and
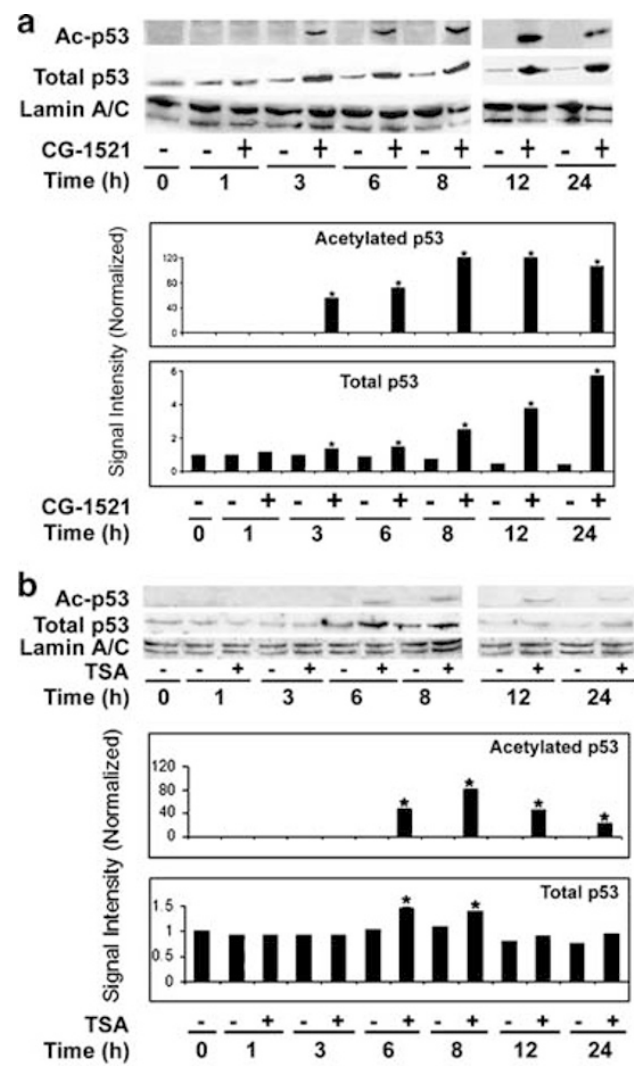

Figure 3 Effect of CG-1521 and TSA on acetylation of p53 and the levels of total p53. CG-1521 induces acetylation of p53 and its subsequent stabilization; TSA transiently induces acetylation of $\mathrm{p} 53$ in LNCaP cells. LNCaP cells were treated with $7.5 \mu \mathrm{M} \mathrm{CG}-1521$ (a) or $5 \mu \mathrm{M}$ TSA (b) for $0-24 \mathrm{~h}$ and nuclear fractions were prepared as described in Materials and Methods. The levels of endogenous acetylated p53, total $p 53$ and lamin $A / C$ were detected by immunoblotting with antiacetylated p53, anti-p53 antibody and anti-lamin A/C antibody. The band intensities of acetylated p53 and total p53 protein levels were measured with Kodak 1D imaging software and normalized against lamin A/C. Results are indicative of three independent experiments

declining rapidly by $24 \mathrm{~h}$ (Figure $3 a$ ). This is mirrored by the small, but statistically significant, transient increase in total p53 levels at 6 and $8 \mathrm{~h}$ of treatment (Figure $3 b$ ).

\section{Treatment with CG-1521 stabilizes the acetylation of p53 at Lys373 while TSA stabilizes the acetylation of p53 at Lys382}

More detailed assessment of the acetylation status of p53 at Lys320, Lys373 and Lys382 in LNCaP cells before and after treatment with CG-1521 or TSA is shown in Figure 4. p53 is acetylated at Lys320 in LNCaP cells prior to treatment, and treatment with CG-1521 (Figure 4a) or TSA (Figure 4b) does not significantly alter the acetylation status of Lys320. The level of acetylation at Lys 373 is significantly elevated by CG1521 by $3 \mathrm{~h}$ and is maintained until $24 \mathrm{~h}$ (Figure $4 \mathrm{a}$ ). On the other hand, acetylation of Lys382 is not affected by treatment with CG-1521. In contrast, TSA has no effect on the acetylation of Lys373, but does significantly increase the levels of p53 acetylated on Lys382 transiently between 6 and 


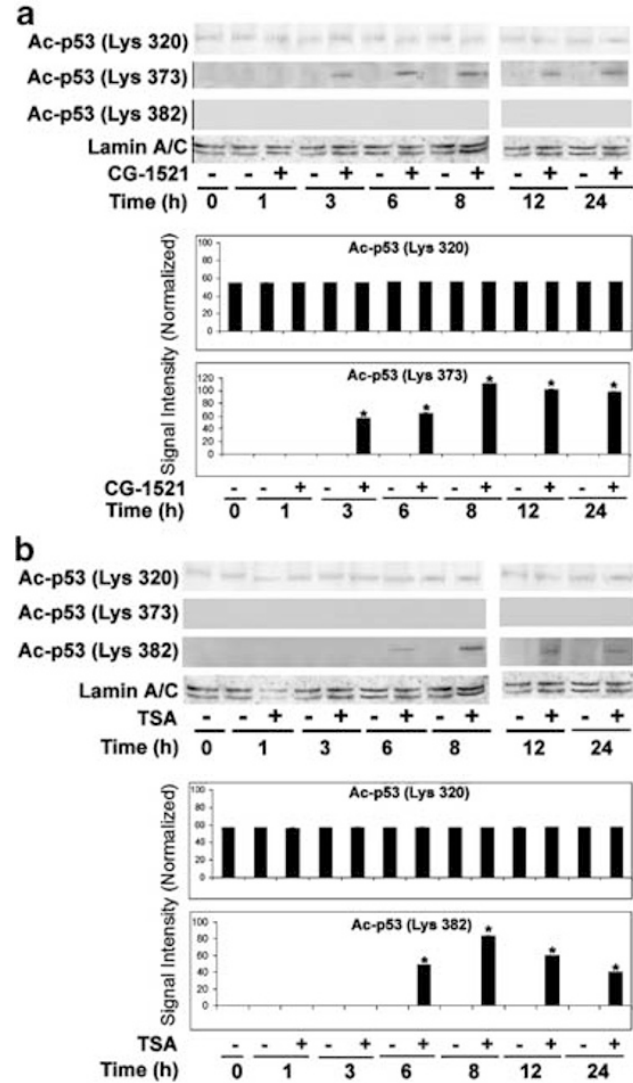

Figure 4 The Effect of CG-1521 and TSA on acetylation of p53 at Lys 320, Lys373 and Lys382. LNCaP cells were treated with $7.5 \mu \mathrm{M}$ CG-1521 (a) or $5 \mu \mathrm{M}$ TSA (b) for $0-24 \mathrm{~h}$, and nuclear fractions were prepared as described in Materials and Methods. The levels of endogenous acetylated p53 at Lys320, Lys373 and Lys382, and lamin $\mathrm{A} / \mathrm{C}$ were detected by immunoblotting with antibodies specific for each of the acetylated lysine residues and antilamin $A / C$ antibody. The band intensities of acetylated p53 at Lys 320 and 373 (a) and Lys 320 and 382 (b) were measured with Kodak $1 \mathrm{D}$ imaging software and normalized against lamin $\mathrm{A} / \mathrm{C}$

$24 \mathrm{~h}$ (Figure 4b). Thus, while both CG-1521 and TSA increase the levels of acetylated p53, they do so by stabilizing the acetylation of different lysine residues in the molecule.

\section{CG-1521 upregulates p21 protein level and induces the translocation and cleavage of Bax in LNCaP cells}

The elevation of p53 levels by $7.5 \mu \mathrm{M} \mathrm{CG-1521} \mathrm{is} \mathrm{accom-}$ panied by the concomitant elevation of $\mathrm{p} 21$ protein levels. The levels of p21 increase gradually, starting at $3 \mathrm{~h}$ and increasing to a level that is approximately six-fold higher than the untreated cells by $48 \mathrm{~h}$ (Figure $5 \mathrm{a}$ ). In addition to the increase in p21 levels, treatment with 7.5 $\mu \mathrm{M}$ CG-1521 also induces the translocation of Bax from the cytosol (S 100) to the mitochondria (NNMF) and subsequent cleavage to t-Bax (Figure $5 b$ ). The level of Bax decreases significantly in the $S$ 100 fraction after $3 \mathrm{~h}$ of treatment and continues to decrease throughout the time frame of the experiment up to $48 \mathrm{~h}$ of treatment. Bax is detected in NNMF as early as $3 \mathrm{~h}$ after treatment and by $12 \mathrm{~h}$, the cleavage product t-Bax, is also
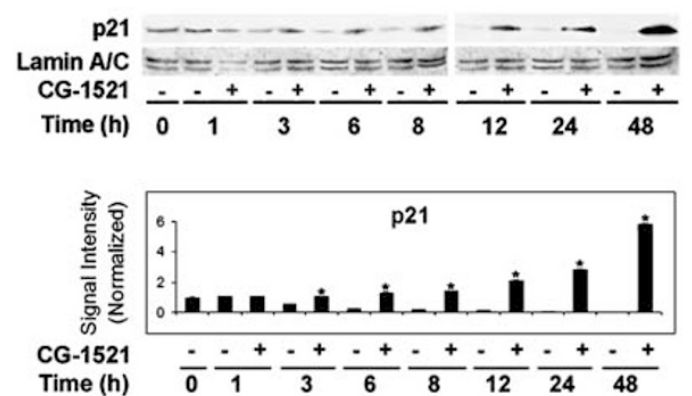

b
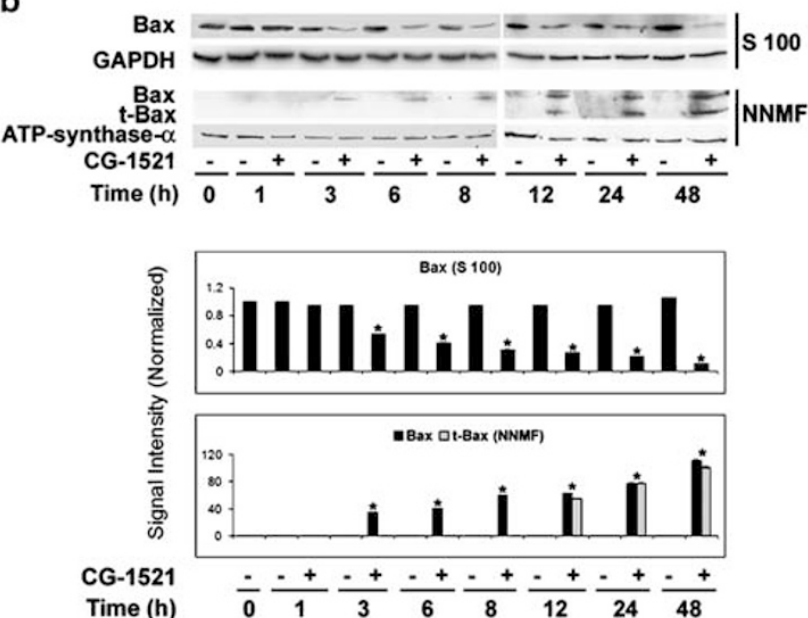

Figure 5 Effect of CG-1521 on protein levels of p21 and Bax and Bax translocation in LNCaP cells. LNCaP cells were treated with $7.5 \mu \mathrm{M}$ CG-1521 for 0-48 $\mathrm{h}$ and nuclear, cytosolic (S 100) and mitochondrial (NNMF) fraction were prepared as described in Materials and Methods. In total, $50 \mu \mathrm{g}$ of protein for nuclear and mitochondrial fraction, and $25 \mu \mathrm{g}$ for cytosolic fraction were analyzed by SDS-PAGE. The levels of endogenous p21 and lamin A/C were detected by immunoblotting. The p21 levels were normalized against lamin A/C (a). The levels of endogenous Bax and GAPDH were measured in the cytosolic (S 100) fraction. Bax, t-Bax and ATP-synthase- $\alpha$ were detected in the mitochondrial fraction by immunoblotting. The signal intensity of Bax and $t-B a x$ were normalized against GAPDH and ATP-synthase- $\alpha$ for cytosolic and mitochondrial fractions respectively (b)

detectable in NNMF. The levels of Bax and t-Bax increase significantly until $48 \mathrm{~h}$ of treatment (Figure $5 \mathrm{~b}$ ).

TSA transiently activates p21, but fails to induce translocation and cleavage of Bax in LNCaP cells

Treatment of LNCaP cells with $5 \mu \mathrm{M}$ TSA induces a small but significant increase in $\mathrm{p} 21$ level, which reaches a maximum at $6 \mathrm{~h}$ before declining to control levels by $48 \mathrm{~h}$ (Figure $6 \mathrm{a}$ ). In contrast, the levels of cytosolic Bax remain unaltered even after $48 \mathrm{~h}$ of treatment and there is no evidence of Bax translocation to the mitochondria or the formation of t-Bax in $\mathrm{LNCaP}$ cells treated with TSA (Figure 6b).

\section{CG-1521 and TSA induce transient activation of p21 but have no effect on the activation of Bax in PC-3 cells}

To determine whether the effects of CG-1521 and TSA are restricted to androgen receptor positive, p53 wild-type cells, 

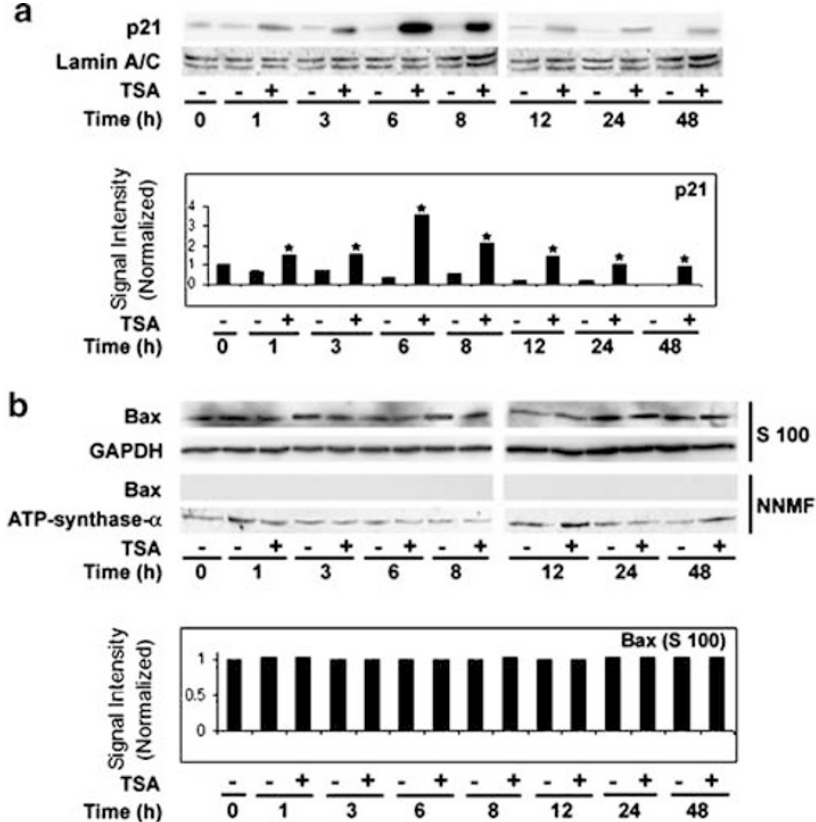

Figure 6 Effect of TSA on protein levels of p21 and Bax and Bax translocation in LNCaP cells. LNCaP cells were treated with $5 \mu \mathrm{M}$ TSA for $0-48 \mathrm{~h}$ and subcellular fractions were prepared as described in Materials and Methods. In total, $50 \mu \mathrm{g}$ of protein for nuclear and mitochondrial fraction, and $25 \mu \mathrm{g}$ for cytosolic fraction were analyzed by SDS-PAGE. The levels of endogenous p21 and lamin $A / C$ detected by immunoblotting and p21 protein levels were normalized against lamin A/C (a). The levels of Bax in the cytosolic fraction (S 100 ) and mitochondrial fraction (NNMF) were normalized using GAPDH and ATP-synthase- $\alpha$ for cytosolic and mitochondrial fractions respectively (b)

the effects of these two HDAC inhibitors on androgen receptor negative, $\mathrm{p5}^{-/-}$, PC-3 cell line were examined. $7.5 \mu \mathrm{M}$ CG1521 induces a transient activation of p21 starting $1 \mathrm{~h}$ after treatment, plateauing between 3 and $6 \mathrm{~h}$ and decreasing by $48 \mathrm{~h}$. However, Bax is detected only in the cytosol (Figure 7a) and there is no evidence of translocation or cleavage of Bax to the mitochondria (Figure 7a). Similarly, treatment of PC-3 cells with $5 \mu \mathrm{M}$ TSA induces a delayed induction of p21, which is first detectable at $6 \mathrm{~h}$, before showing a similar decrease in the levels to baseline as seen after treatment with CG-1521 (Figure 7b). The levels of Bax in the cytosol are not affected by TSA in PC-3 cells and there is no translocation of Bax to the mitochondria or cleavage to t-Bax (Figure 7b).

\section{Differences in the effects of CG-1521 and TSA are a result of different target HDACs}

A number of HDACs have been identified in human cell lines. A survey of the major HDACs in LNCaP and PC-3 cells was conducted. Both cell lines express HDAC1; however, the levels do not alter in these cell lines after treatment with either CG-1521 or TSA (Figure 8). Similar data were found for HDAC3 and HDAC4 (data not shown). Only the LNCaP cell line expresses HDAC2, (Figure 8a), and the level of HDAC2 is significantly affected by treatment with $7.5 \mu \mathrm{M}$ CG-1521, decreasing to undetectable levels by $48 \mathrm{~h}$ after treatment. In a
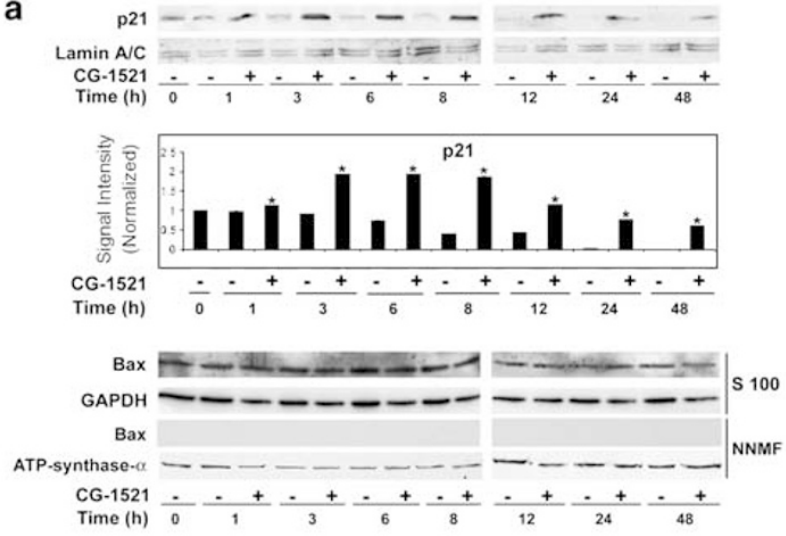

b
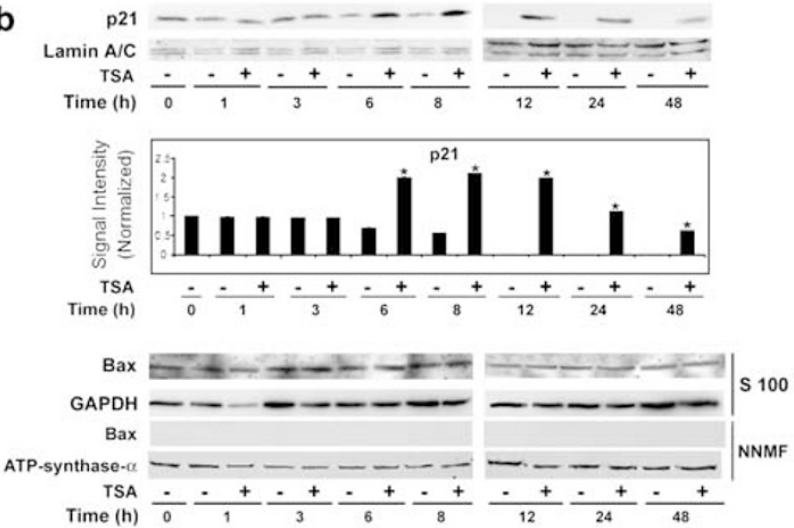

Figure 7 The Effect of CG-1521 and TSA on p21 and Bax protein levels and Bax translocation in PC-3 cells. PC-3 cells were treated with $7.5 \mu \mathrm{M} \mathrm{CG}-1521$ (a) or $5 \mu \mathrm{M}$ TSA (b) for $0-48 \mathrm{~h}$ and subcellular fractions were prepared as described in Materials and Methods. In total, $50 \mu \mathrm{g}$ of protein for nuclear and mitochondrial fraction, and $25 \mu \mathrm{g}$ for cytosolic fraction were analyzed by SDS-PAGE. The endogenous levels of p21 and lamin A/C were detected by immunoblotting and p21 protein levels were normalized against lamin $A / C$. The levels of $B a x$ in the cytosolic fraction (S 100) and mitochondrial fraction (NNMF) were detected by immunoblotting and normalized using GAPDH (for cytosolic proteins) and ATPsynthase- $\alpha$ (for mitochondrial proteins)

contrast $5 \mu \mathrm{M}$ TSA has no significant effect on the level of HDAC2 in LNCaP cells.

\section{Discussion}

In this report we show that CG-1521 is a potent inducer of cell cycle arrest and apoptosis in the androgen receptor positive prostate cancer cell line LNCaP. Like other histone deacetylase inhibitors, CG-1521 blocks the de-acetylation of H3 and $\mathrm{H} 4$, quantitatively the major targets of HDAC activity in the cell. ${ }^{2-5}$ Stabilization of the acetylated histones by CG-1521 is evident as early as $1 \mathrm{~h}$ after treatment, well before the morphological evidence of apoptosis and cell cycle arrest, suggesting that the re-expression of genes that regulate differentiation or cell death through changes in chromatin conformation might be responsible for the effects of CG-1521 on cell cycle kinetics and apoptosis. However, in addition to stabilizing the acetylation of histones, treatment with CG-1521 also causes an increase in the level of acetylated p53 and total 
a
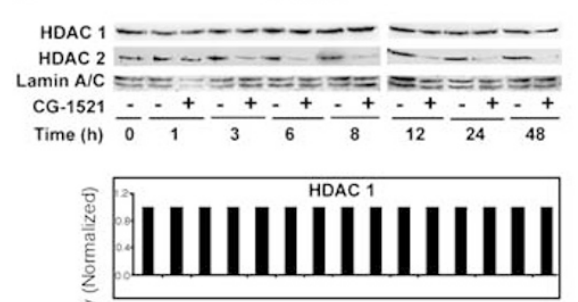

竞

CG-1521

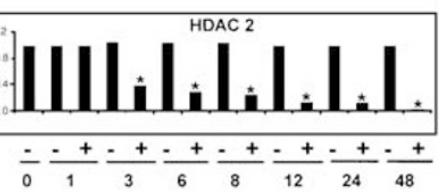

b
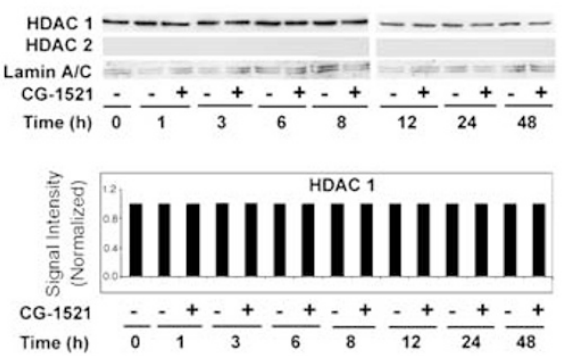

LNCaP
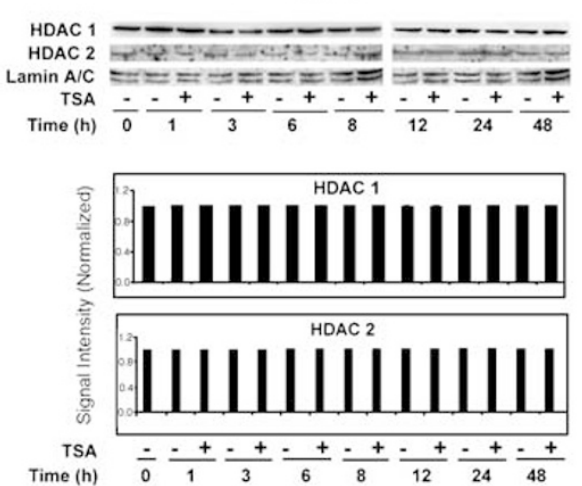

PC-3
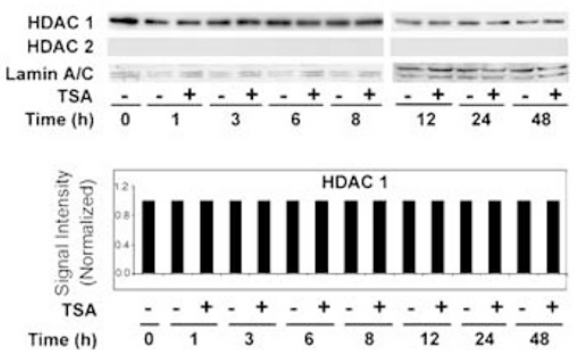

Figure 8 The effects of CG-1521 and TSA on HDAC 1 and HDAC 2 in LNCaP and PC-3 cells. LNCaP (a) and PC-3 cells (b) were treated with $7.5 \mu$ M CG-1521 or $5 \mu$ M TSA for $0-48 \mathrm{~h}$ and nuclear fractions were prepared as in Materials and Methods. The endogenous levels of HDAC1, HDAC2 and lamin A/C were detected by immunoblotting. The changes in HDAC1 and HDAC2 were normalized against lamin A/C

p53 as early as $3 \mathrm{~h}$ after treatment. This suggests that CG1521 may directly target proteins involved in cellular responses, particularly in apoptosis and cell cycle arrest, and that the effects of CG-1521 on changes in cell function through chromatin remodeling may be a secondary, rather than primary, effect.

Using an antibody that recognizes p53 acetylated at Lys373 or Lys382, we provide evidence that CG-1521 blocks the deacetylation of p53 as early as $3 \mathrm{~h}$ after treatment, which leads to a concomitant, sustained increase in the total level of p53 in the cell. However, when the same cell line is treated with TSA, the increase of p53 acetylation at these two sites is not as pronounced and the increase in total p53 levels is significantly more transient. Two recent reports have suggested that acetylation is important for p53 to suppress oncogenic rasinduced transformation ${ }^{39}$ and to induce metaphase chromosome fragility, ${ }^{40}$ suggesting that acetylation of the protein may be essential for many functions of p53. The findings that p300/ CBP acetyltransferases and $\mathrm{p} 19^{\mathrm{ARF}}$ promote $\mathrm{p} 53$ acetylation in vivo, while MDM2 inhibits acetylation, ${ }^{41}$ further supports the idea that acetylation is an important modification targeted by both positive and negative regulators critical to p53 tumor suppressor activity. p300/CBP-mediated acetylation and MDM2-mediated ubiquitinylation of p53 have been shown to occur at a common set of lysine residues in p53 (Lys320, Lys373 and Lys 382). Further dissection of the acetylation of p53 using antibodies specific for acetylated-Lys320, acetylated-Lys373 and acetylated-Lys382 demonstrates that the two inhibitors target different lysine residues in p53. In LNCaP cells, the acetylation of Lys320 appears to be constitutive and is not affected by either CG-1521 or TSA. However, TSA selectively blocks the de-acetylation of Lys382, while CG1521 targets the acetylation of Lys373. Acetylation of p53 at Lys382 has been shown to prevent the MDM-2 mediated ubiquitinylation and subsequent proteasomal degradation of p53, a process that is known to be blocked by TSA. ${ }^{42}$ Since Lys 373 is also targeted by MDM-2, CG-1521 appears to be blocking the degradation of p53 by preventing the deacetylation of Lys373 and subsequent ubiqutination and proteasomal degradation of p53, leading to the increase in the levels of p53 in LNCaP cells. Treatment with CG-1521 induces a marked decrease in the protein level of HDAC2 in LNCaP cells possibly through proteasome-mediated degradation as has been demonstrated to occur in K562 human erythroleukemia cells, F9 mouse teratocarcinoma and HEK293T human embryonic kidney carcinoma cells after treatment with another histone deacetylase inhibitor, valproic acid. ${ }^{43}$ This decrease in HDAC2 activity occurs concurrently with the stabilization of acetylated Lys373 p53, suggesting that HDAC2 is also involved in the deacetylation of this residue in p53 either alone or complexed with HDAC1 ${ }^{44}$ Since CG1521 markedly downregulates the protein level of HDAC2 in LNCaP cells, this would suggest that the stabilization of acetylation at Lys373 is mediated by HDAC2 (and only affected by CG-1521) whereas the stabilization of acetylation at Lys382 is mediated by HDAC1, which is inhibited by TSA. 
Further studies will be required to elucidate the individual role of these deacetylases in regulating p53 function. However, the participation of multiple deacetylases supports the idea that acetylation is a critical mechanism for regulation of p53.

Stabilization of $p 53$ leads to the activation of downstream targets, including $\mathrm{p} 21^{\mathrm{WAF}-1 / \mathrm{CIP}-1}$ and Bax due to the induction of transcription through the well-characterized p53 binding sites in the promoters of these two genes. ${ }^{45,46}$ Consistent with this idea, we have shown that the stabilization of acetylated p53 induces the upregulation of p21 WAF-1/CIP-1 protein levels. It has recently been demonstrated that p53 cooperates with the transcription factor Sp1, through binding to the C-terminal domain of Sp1 to induce transcription of the p21 gene, while binding of HDAC1 to the same domain inhibits the transcription. ${ }^{47}$ Since the protein levels of HDAC1 do not change significantly after treatment with either CG-1521 or TSA, this suggests that the enzymatic activity of HDAC1 is required for interaction with $\mathrm{Sp} 1$. If this is the case, both TSA and CG-1521 may contribute to the induction of p21 transcription through a p53-independent mechanism by relieving the inhibition by HDAC1 in both LNCaP (p53 wild type) and PC-3 (p53 null) cells. In LNCaP cells, the stabilization of acetylated p53 may further increase the transcription of the p21 gene, possibly explaining the more prolonged induction of the protein in LNCaP cells.

The role of $p 21$ in inducing $G_{1} / S$ phase arrest through its interactions with cyclin $\mathrm{E} / \mathrm{cdk} 2$ is well established; ${ }^{48}$ however, p21 induction in several p53 null cells, including the PC-3M prostate cancer sub-line, ${ }^{49}$ has also been shown to induce $\mathrm{G}_{2} / \mathrm{M}$ arrest. There are several possible mechanisms that might lead to $G_{2} / M$ arrest. TSA has been shown to produce $\mathrm{G}_{2} / \mathrm{M}$ arrest in $\mathrm{p53}^{-/-} \mathrm{MG} 63$ osteosarcoma cells through the induction of Gadd45, a process that requires both the Oct-1 and NF-Y (CCAAT) sites in the promoter. ${ }^{50}$ In human myeloma cells and EBV + lymphoblastic cell lines decitabine (a DNA demethylating agent) induces cell cycle arrest at $G_{1}$ (through transcriptional induction of $p 21$ ) and at $\mathrm{G}_{2} / \mathrm{M}$ through activation of the p38 MAP kinase pathway. ${ }^{51}$ The current studies indicate that the induction of $\mathrm{p} 21$ by $\mathrm{CG}-1521$ primarily regulates cell cycle arrest at $\mathrm{G}_{2} / \mathrm{M}$ in $\mathrm{LNCaP}$ cells. While this might suggest that this arrest is independent of $p 53$ activation, the increase of the percentage of cells arrested in the $G_{0} / G_{1}$ phase seen at higher concentrations of the drug raises the possibility that both $\mathrm{G}_{2} / \mathrm{M}$ and $\mathrm{G}_{0} / \mathrm{G}_{1}$ arrest are regulated by CG-1521 in a dose-dependent manner in p53 $3^{+/+}$cells. Thus, while it is clear that CG-1521 can induce p21 levels in LNCaP cells by a p53 mediated pathway, it is not clear whether this pathway is the predominant pathway in $\mathrm{p} 53^{+/+}$cells, or whether p21 is induced by both p53-dependent and -independent pathways in these cells.

Bax (and consequently cell death) is only induced in LNCaP cells by CG-1521, suggesting that the two histone deacetylase inhibitors have different, and possibly additional mechanisms of action. The data presented in this manuscript cannot distinguish between the differences in the induction of Bax transcription by CG-1521 and TSA and the possibility that CG-1521 induces Bax translocation and cleavage via a mechanism that is completely independent of the p53 acetylation. However, given the recent demonstration that transfection of p53 mutated at either Lys320 or Lys373, but not Lys382, renders $\mathrm{p5} 3^{-1-}$ KATO-III cells resistant to induction of apoptosis by histone deacetylase inhibitors, ${ }^{52}$ it is attractive to hypothesize that the activation of the bax promoter requires the participation of p53 acetylated at Lys320 and Lys373, in much the same way as the induction of PIG3 and NOXA in KATO-III, while the p53-dependent induction of p21 requires the participation of p53 acetylated at either site. These data also suggest that the tissue-specific effects of histone deacetylase inhibitors will depend in part on which HDACs are expressed in the cell, which nuclear proteins and which bromodomain proteins are present in the cell. ${ }^{53}$ Distinguishing between these possibilities will require further experimentation, but the data presented here suggest that the choice of HDAC inhibitor to be tested for clinical intervention will largely depend on the HDAC isoenzyme-specific target genes present in the cells and the complement of HDACs in the cell.

\section{Materials and Methods}

\section{Cell culture}

$\mathrm{LNCaP}$ and PC-3 human prostate cancer cells, obtained from American Type Culture Collection (Rockville, MD, USA), were cultured in RPMI-1640 (Life Technologies, Gaithersburg, MD, USA) and Ham's F-12K (Sigma, St Louis, MO, USA) respectively, with $10 \%$ fetal bovine serum (Atlas, Fort Collins, CO, USA). All cell lines were routinely passaged every $3-4$ days.

\section{Crystal violet growth assay}

For growth assays, LNCaP and PC-3 cells were plated at a density of $2 \times 10^{4}$ cells/well and $1 \times 10^{4}$ cells/well respectively in 24-well plates. Treatments with CG-1521 (Circagen Pharmaceuticals, Phoenix, MD, USA), or DMSO vehicle (as a time matched negative control) were initiated $24 \mathrm{~h}$ after plating. After 24-96 h of treatment, Crystal Violet growth assays were performed according to the manufacturer's directions (Fisher Scientific, Pittsburgh, PA, USA).

\section{Flow cytometry}

Cells were seeded in T-150 flasks at a density of $5 \times 10^{6}$ cells/flask, and $24 \mathrm{~h}$ after plating were treated for a period of $48 \mathrm{~h}$. Cells were stained with $5 \mu \mathrm{g} / \mathrm{ml}$ propidium iodide (PI), (Sigma) containing RNAse (Roche Diagnostics) for $30 \mathrm{~min}$. At least 10000 cells per treatment were analyzed on a Coulter Epics XL cytometer (Coulter, Miami, FL, USA) and cell cycle modeling was performed using Multiplus AV software (Phoenix Flow Systems). Apoptosis was measured by flow cytometry by terminaltransferase mediated labeling of DNA strand breaks. Cells were fixed in $2 \%$ formaldehyde, washed twice in PBS $/ 0.2 \%$ BSA, and permeabilized with $70 \%$ ethanol at $-20^{\circ} \mathrm{C}$ for at least $1 \mathrm{~h}$. DNA strand breaks were labeled with bromodeoxyuridine by terminal transferase (Roche Diagnostics) and detected using the Apo-BrdU detection kit according to the manufacturer's directions (Phoenix Flow Systems, San Diego, CA, USA). Cells were counterstained with propidium iodide, and at least 10000 cells were analyzed and modeled utilizing Multiplus AV software (Phoenix Flow Systems).

\section{Extraction of cellular histones}

Histones were extracted according to previous procedure. ${ }^{20}$ Approximately $2 \times 10^{6}$ cells cultured in the absence or presence of $7.5 \mu \mathrm{M}$ 
CG-1521 were harvested, collected by centrifugation at $700 \times g$ for $10 \mathrm{~min}$, washed once with phosphate-buffered saline and suspended in ice-cold lysis buffer (10 mM Tris- $\mathrm{HCl}, 50 \mathrm{mM}$ sodium bisulfite, $1 \%$ Triton $\mathrm{X}$ $100,10 \mathrm{mM} \mathrm{MgCl}_{2}, 8.6 \%$ sucrose, $\mathrm{pH}$ 6.5). Cells were Dounce homogenized and nuclei were collected by centrifugation at $1000 \times g$ for $10 \mathrm{~min}$, washed three times with lysis buffer and once with $10 \mathrm{mM}$ Tris$\mathrm{HCl}, 13 \mathrm{mM}$ EDTA, pH 7.4. The pellet was suspended in $0.1 \mathrm{ml}$ of ice-cold $\mathrm{H}_{2} \mathrm{O}$ and concentrated $\mathrm{H}_{2} \mathrm{SO}_{4}$ was added to the suspension to a final concentration of $0.4 \mathrm{~N}$. After incubation at $4^{\circ} \mathrm{C}$ for $1 \mathrm{~h}$, the suspension was centrifuged for $5 \mathrm{~min}$ at $15000 \mathrm{rpm}$ and the supernatant was taken and mixed with $1 \mathrm{ml}$ acetone, incubated overnight at $-20^{\circ} \mathrm{C}$, centrifuged for $5 \mathrm{~min}$ at $15000 \mathrm{rpm}$ and pellet, air dried. The acid soluble histone fraction was dissolved in $50 \mu \mathrm{L}$ of $\mathrm{H}_{2} \mathrm{O}$. Protein concentrations were determined by the Micro BCA protein assay (Pierce, Rockford, IL, USA).

\section{Separation and analysis of histones}

Acetylation of histones was analyzed by minislab gel electrophoresis using acid/urea/triton (AUT) minislab gel ( $5 \%$ acetic acid, $7.5 \mathrm{M}$ urea, $6 \mathrm{mM}$ Triton X-100, $12 \%$ acrylamide), as described in Linnox and Cohen. ${ }^{54}$ $10 \mu \mathrm{g}$ of the extracted histones were loaded into the AUT gel and electrophoresed at $100 \mathrm{~V}$ for $4 \mathrm{~h}$. Before transferring on to nitrocellulose membranes for Western analysis, the AUT gels were washed on a rotary shaker for $30 \mathrm{~min}$ in $150 \mathrm{ml}$ of $50 \mathrm{mM}$ acetic acid, containing $0.5 \%$ SDS. The proteins were transferred onto nitrocellulose membrane $(8 \times 9 \mathrm{~cm}$, $22 \mu \mathrm{m}$ pore size, Osmonics Inc.) positioned at the anode side of the gel, with transfer buffer (25 mM Tris, $192 \mathrm{mM}$ Glycine, 0.1\% SDS, pH 8.3 and $20 \% \mathrm{v} / \mathrm{v}$ methanol), in a Bio-Rad mini transblot apparatus at constant $100 \mathrm{~V}$ for $10 \mathrm{~min}$ followed by constant $60 \mathrm{~V}$ for $50 \mathrm{~min} .{ }^{55}$ After transfer, the nitrocellulose membrane was probed with a 1:1000 dilution of antiacetylHistone H3 antibody (Cat \# 06-599; Upstate Biotechnology, Lake Placid, NY, USA), 1:1000 dilution of antihistone H3 antibody (Cat \# 05-499; Upstate Biotechnology), $1: 1000$ dilution of antiacetyl-Histone $\mathrm{H} 4$ antibody (Cat \# 06-598; Upstate Biotechnology) or 1: 1000 dilution of antihistone H4 antibody (Cat \# 07-108; Upstate Biotechnology), followed by a 1: 5000 dilution of horseradish peroxidase-conjugated secondary antibody against respective rabbit $\lg G$ and mouse $\lg G$ and autoradiographed with Super Signal West Dura extended duration substrate (Cat \# 34075; Pierce, Rockford, IL, USA). Blots were stripped with Western Re-Probe ${ }^{\text {TM }}$ Buffer (Cat \# 786-119; Geno Technology, St. Louis, MO, USA).

\section{Total cell lysate}

Total cell lysates were prepared essentially according to Yang et $a l .{ }^{56}$ Cells were scraped and pelleted by centrifugation at $1500 \mathrm{rpm}$ for $3 \mathrm{~min}$ at $4^{\circ} \mathrm{C}$. Pellets were resuspended in ice-cold wash buffer $(25 \mathrm{mM}$ Tris, $\mathrm{pH} 7.5$, $250 \mathrm{mM}$ sucrose, $2.5 \mathrm{mM} \mathrm{MgCl} 2,10 \mathrm{mM}$ benzamidine, $10 \mathrm{mM} \mathrm{NaF}, 1 \mathrm{mM}$ sodium vanadate, $10 \mu \mathrm{g} / \mathrm{ml}$ leupeptin, $10 \mu \mathrm{g} / \mathrm{ml}$ aprotinin, $1 \mu \mathrm{g} / \mathrm{ml}$ pepstatin and $1 \mathrm{mM} P M S F)$, pelleted at $1500 \mathrm{rpm}$ for $3 \mathrm{~min}$ at $4^{\circ} \mathrm{C}$ and resuspended in Buffer $\mathrm{A}(20 \mathrm{mM}$ HEPES-KOH, pH 7.5, $10 \mathrm{mM} \mathrm{KCl}$, $1.5 \mathrm{mM} \mathrm{MgCl}_{2}, 1 \mathrm{mM}$ EDTA, $1 \mathrm{mM}$ EGTA, $250 \mathrm{mM}$ sucrose, $1 \mathrm{mM}$ sodium vanadate, $1 \mathrm{mM}$ DTT, $25 \mu \mathrm{g} / \mathrm{ml}$ leupeptin, $25 \mu \mathrm{g} / \mathrm{ml}$ aprotinin, $2.5 \mu \mathrm{g} / \mathrm{ml}$ pepstatin, $1 \mathrm{mM}$ PMSF, $10 \mathrm{mM}$ benzamidine and $20 \mathrm{mM} \mathrm{NaF}$ ), Dounce homogenized and stored at $-20^{\circ} \mathrm{C}$. Protein concentrations were determined by the Micro BCA assay (Pierce, Rockford, IL, USA).

\section{Subcellular fractionation}

Subcellular fractions were isolated as previously described. ${ }^{54}$ Cells were scraped, pelleted by centrifugation at $1500 \mathrm{rpm}$ for $3 \mathrm{~min}$ at $4^{\circ} \mathrm{C}$, resuspended in ice-cold wash buffer and pelleted at $1500 \mathrm{rpm}$ for $3 \mathrm{~min}$ at $4{ }^{\circ} \mathrm{C}$. Pellets were resuspended with three volumes of Buffer $A$ and lysed with a Dounce homogenizer. Homogenates were centrifuged twice at $1500 \mathrm{rpm}$ for $6 \mathrm{~min}$ at $4^{\circ} \mathrm{C}$ and the nuclear pellets were resuspended in Buffer $\mathrm{A}$, sonicated for $20 \mathrm{~s}$, and stored at $-20^{\circ} \mathrm{C}$. The supernatants were ultracentrifuged at $55000 \mathrm{rpm}$ (Beckman TLA 120.2) for $1 \mathrm{~h}$ at $4^{\circ} \mathrm{C}$. The resultant pellets containing the mitochondria, and designated the nonnuclear membrane fraction (NNMF) were resuspended in Buffer A, sonicated three times for $20 \mathrm{~s}$ each, and stored at $-20^{\circ} \mathrm{C}$. The supernatant containing cytosolic fraction was designated $S 100$ and stored at $-20^{\circ} \mathrm{C}$. Protein concentrations were determined by the Micro BCA protein assay (Pierce, Rockford, IL, USA).

\section{Western blot analysis}

Total cell lysate $(50 \mu \mathrm{g})$, nuclear fraction $(50 \mu \mathrm{g})$, NNMF $(50 \mu \mathrm{g})$ and cytosolic fraction $\mathrm{S} 100(25 \mu \mathrm{g})$ isolated as described above were solubilized in loading buffer containing $5 \% \beta$-mercaptoethanol, separated by SDS-PAGE, and transferred on to nitrocellulose. Equal loading and transfer of proteins were confirmed by Ponceau-S staining (BDH, Dorset, England). Protein derived from total cell lysate, nuclear, NNMF and S 100 extracts were immunoblotted with antiacetyl p53 (Lys373 and Lys382) rabbit antiserum (Cat \# 06-758; Upstate Biotechnology, Lake Placid, NY), antacetyl p53 (Lys373) (Cat \# 06-916, Upstate Biotechnology Lake Placid NY, USA), antiacetyl p53 (Lys382) (Cat \# 01-010-179M, American Proteomics, Carlsbad, CA, USA), anti-p53 mouse monoclonal (Cat \# 05224; Upstate Biotechnology, Lake Placid, NY, USA), antilamin A/C goat polyclonal (N-18; Santa Cruz Biotech., Santa Cruz, CA, USA), antip21 ${ }^{\text {WAF1/CIP1 }}$ mouse monoclonal (Cat \# OP68; Oncogene Research Products, San Diego, CA, USA), anti-Bax rabbit polyclonal (Cat \# 554104; BD Pharmingen, San Diego, CA, USA), anti-GAPDH mouse monoclonal (Cat \# 4699-9555; Biogenesis, Kingston, NH, USA), anti-ATP synthase- $\alpha$ mouse monoclonal antibodies (Cat \# A11144; Molecular Probes, Eugene, OR, USA), anti-HDAC1 mouse monoclonal (Cat \# 05-614; Upstate Biotechnology, Lake Placid, NY, USA), anti-HDAC2 rabbit polyclonal (Cat \# 07-222; Upstate Biotechnology, Lake Placid, NY, USA), or anti-HDAC3 rabbit polyclonal (Cat \# 06-890; Upstate Biotechnology, Lake Placid, NY, USA), diluted in blocking solution ( $5 \%$ milk in $0.05 \%$ PBS-Tween). Specific antibody binding was detected by goat anti-mouse (Cat \# 170-6516; BioRad Lab, Hercules, CA, USA), goat-anti rabbit (Cat \# 170-6515; Bio-Rad Lab, Hercules, CA, USA) or rabbit anti-goat (Cat \# 31402; Pierce, Rockford, IL, USA) IgG antibody conjugated with horseradish peroxidase diluted 1:5000 or 1:10000 in blocking solution and autoradiographed with enhanced chemiluminescence (Pierce). The membranes were stripped with Western Re-Probe ${ }^{\mathrm{TM}}$ Buffer (Cat \# 786-119; Geno Technology, St. Louis, MO, USA). The band intensities in all cell lines were measured and analyzed with the Kodak 1D imaging software. Changes in protein levels were normalized relative to the appropriate loading control (lamin A/C for the nuclear fraction; GAPDH for the cytosolic fraction, and ATP-synthase- $\alpha$ for the mitochondrial fraction).

\section{Statistical analysis}

Data are expressed as the mean \pm standard error (SE). One-way analysis of variance (ANOVA) was used to assess statistical significance between means. Differences between means were considered significant when $P<0.001$ using the Bonferroni post-test. All statistical analyses were performed with the GraphPad Instat software (Intuitive Software for Science, San Diego, CA, USA). 


\section{Acknowledgements}

We thank Drs. Carmen J Narvaez, Louise Flanagan, Paul Huber and JoEllen Welsh for their valuable advice and critical reading of this manuscript. The research was supported by the Coleman Foundation and an unrestricted grant from Circagen Inc.

\section{References}

1. Emiliani S, Fischle W, Van Lint C, Al-Abed Y and Verdin E (1998) Characterization of a human RPD3 ortholog, HDAC3. Proc. Natl. Acad. Sci. USA 95: 2795-2800

2. Grunstein M (1997) Histone acetylation in chromatin structure and transcription. Nature 389: 349-352

3. Hebbes TR, Thorne AW and Crane-Robinson C (1988) A direct link between core histone acetylation and transcriptionally active chromatin. EMBO J. 7: 1395-1402

4. Loidl P (1994) Histone acetylation: facts and questions. Chromosoma 103 : 441-449

5. Tazi J and Bird A (1990) Alternative chromatin structure at CpG islands. Cell 60: 909-920

6. Torchia J, Glass C and Rosenfeld MG (1998) Co-activators and co-repressors in the integration of transcriptional responses. Curr. Opin. Cell Biol. 10: 373-383

7. Nagy L, Kao HY, Chakravarti D, Lin RJ, Hassig CA, Ayer DE, Schreiber SL and Evans RM (1997) Nuclear receptor repression mediated by a complex containing SMRT, mSin3A, and histone deacetylase. Cell 89: 373-380

8. Alland L, Muhle R, Hou Jr H, Potes J, Chin L, Schreiber-Agus $\mathrm{N}$ and DePinho RA (1997) Role for N-CoR and histone deacetylase in Sin3-mediated transcriptional repression. Nature 387: 49-55

9. Heinzel T, Lavinsky RM, Mullen TM, Soderstrom M, Laherty CD, Torchia J, Yang WM, Brard G, Ngo SD, Davie JR, Seto E, Eisenman RN, Rose DW, Glass CK and Rosenfeld MG (1997) A complex containing N-CoR, mSin3 and histone deacetylase mediates transcriptional repression. Nature 387: 43-48

10. Brehm A, Miska EA, McCance DJ, Reid JL, Bannister AJ and Kouzarides T (1998) Retinoblastoma protein recruits histone deacetylase to repress transcription. Nature 391: 597-601

11. Magnaghi-Jaulin L, Groisman R, Naguibneva I, Robin P, Lorain S, Le Villain JP, Troalen F, Trouche D and Harel-Bellan A (1998) Retinoblastoma protein represses transcription by recruiting a histone deacetylase. Nature 391: 601-605

12. Hassig CA, Fleischer TC, Billin AN, Schreiber SL and Ayer DE (1997) Histone deacetylase activity is required for full transcriptional repression by $\mathrm{mSin} 3 \mathrm{~A}$. Cell 89: 341-347

13. Laherty CD, Yang WM, Sun JM, Davie JR, Seto E and Eisenman RN (1997) Histone deacetylases associated with the mSin3 corepressor mediate mad transcriptional repression. Cell 89: 349-356

14. Doetzlhofer A, Rotheneder H, Lagger G, Koranda M, Kurtev V, Brosch G, Wintersberger $E$ and Seiser $C$ (1999) Histone deacetylase 1 can repress transcription by binding to Sp1. Mol. Cell. Biol. 19: 5504-5511

15. Gray SG and Ekström TJ (2001) The human histone deacetylase family. Exp. Cell Res. 262: 75-83

16. Krämer $\mathrm{OH}$, Gottlicher $\mathrm{M}$ and Heinzel $\mathrm{T}$ (2001) Histone deacetylase as a therapeutic target. Trends Endocrinol. Metab. 12: 294-300

17. Marks PA, Richon VM, Breslow R and Rifkind RA (2001) Histone deacetylase inhibitors as new cancer drugs. Curr. Opin. Oncol. 13: 477-483

18. Melnick A and Licht JD (2002) Histone deacetylases as therapeutic targets in hematologic malignancies. Curr. Opin. Hematol. 9: 322-332

19. Ogryzko VV, Hirai TH, Russanova VR, Barbie DA and Howard BH (1996) Human fibroblast commitment to a senescence-like state in response to histone deacetylase inhibitors is cell cycle dependent. Mol. Cell. Biol. 16: 5210-5218

20. Yoshida M, Kijima M, Akita M and Beppu T (1990) Potent and specific inhibition of mammalian histone deacetylase both in vivo and in vitro by trichostatin $A . J$. Biol. Chem. 265: 17174-17179

21. Yoshida M, Nomura $S$ and Beppu $T$ (1987) Effects of trichostatins on differentiation of murine erythroleukemia cells. Cancer Res. 47: 3688-3691

22. Cohen LA, Amin S, Marks PA, Rifkind RA, Desai D and Richon VM (1999) Chemoprevention of carcinogen-induced mammary tumorigenesis by the hybrid polar cytodifferentiation agent, suberanilohydroxamic acid (SAHA) Anticancer Res. 19: 4999-5005

23. Richon VM, Webb Y, Merger R, Sheppard T, Jursic B, Ngo L, Civoli F, Breslow R, Rifkind RA and Marks PA (1996) Second generation hybrid polar compounds are potent inducers of transformed cell differentiation. Proc. Natl. Acad. Sci. USA 93: 5705-5708

24. Vrana JA, Decker RH, Johnson CR, Wang Z, Jarvis WD, Richon VM, Ehinger M, Fisher PB and Grant S (1999) Induction of apoptosis in U937 human leukemia cells by suberoylanilide hydroxamic acid (SAHA) proceeds through pathways that are regulated by $\mathrm{Bcl}-2 / \mathrm{Bcl}-\mathrm{XL}$, c-Jun, and $\mathrm{p} 21 \mathrm{CIP} 1$, but independent of p53. Oncogene 18: 7016-7025

25. Kijima M, Yoshida M, Sugita K, Horinouchi S and Beppu T (1993) Trapoxin, an antitumor cyclic tetrapeptide, is an irreversible inhibitor of mammalian histone deacetylase. J. Biol. Chem. 268: 22429-22435

26. Richon VM, Emiliani S, Verdin E, Webb Y, Breslow R, Rifkind RA and Marks PA (1998) A class of hybrid polar inducers of transformed cell differentiation inhibits histone deacetylases. Proc. Natl. Acad. Sci. USA 95: 3003-3007

27. Warrell Jr RP, He LZ, Richon V, Calleja E and Pandolfi PP (1998) Therapeutic targeting of transcription in acute promyelocytic leukemia by use of an inhibito of histone deacetylase. J. Natl. Cancer Inst. 90: 1621-1625

28. Levine AJ (1997) p53, the cellular gatekeeper for growth and division. Cell 88 323-331

29. Prives $C$ and Hall PA (1999) The p53 pathway. J. Pathol. 187: 112-126

30. Vogelstein B, Lane D and Levine AJ (2000) Surfing the p53 network. Nature 408: $307-310$

31. Nakano K and Vousden KH (2001) PUMA, a novel proapoptotic gene, is induced by p53. Mol. Cell 7: 683-694

32. Yu J, Zhang L, Hwang PM, Kinzler KW and Vogelstein B (2001) PUMA induces the rapid apoptosis of colorectal cancer cells. Mol. Cell 7: 673-682

33. Appella E and Anderson CW (2000) Signaling to p53: breaking the posttranslational modification code. Pathol. Biol. (Paris) 48: 227-245

34. Gu W and Roeder RG (1997) Activation of p53 sequence-specific DNA binding by acetylation of the p53 C-terminal domain. Cell 90: 595-606

35. Gu W, Shi XL and Roeder RG (1997) Synergistic activation of transcription by CBP and p53. Nature 387: 819-823

36. Liu L, Scolnick DM, Trievel RC, Zhang HB, Marmorstein R, Halazonetis TD and Berger SL (1999) p53 sites acetylated in vitro by PCAF and p300 are acetylated in vivo in response to DNA damage. Mol. Cell. Biol. 19: 1202-1209

37. Sakaguchi K, Herrera JE, Saito S, Miki T, Bustin M, Vassilev A, Anderson CW and Appella E (1998) DNA damage activates p53 through a phosphorylationacetylation cascade. Genes Dev. 12: 2831-2841

38. Liu Y, Colosimo AL, Yang XJ and Liao D (2000) Adenovirus E1B 55kilodalton oncoprotein inhibits p53 acetylation by PCAF. Mol. Cell. Biol. 20: 5540-5553

39. Pearson M, Carbone R, Sebastiani C, Cioce M, Fagioli M, Saito S, Higashimoto Y, Appella E, Minucci S, Pandolfi PP and Pelicci PG (2000) PML regulates p53 acetylation and premature senescence induced by oncogenic Ras. Nature 406 207-210

40. Yu A, Fan HY, Liao D, Bailey AD and Weiner AM (2000) Activation of p53 or loss of the Cockayne syndrome group $B$ repair protein causes metaphase fragility of human U1, U2, and $5 S$ genes. Mol. Cell 5: 801-810

41. Ito A, Lai CH, Zhao X, Saito S, Hamilton MH, Appella E and Yao TP (2001) p300/CBP-mediated p53 acetylation is commonly induced by p53-activating agents and inhibited by MDM2. EMBO J. 20: 1331-1340

42. Ito A, Kawaguchi Y, Lai CH, Kovacs JJ, Higashimoto Y, Appella E and Yao TP (2002) MDM2-HDAC1-mediated deacetylation of p53 is required for its degradation. EMBO J. 21: 6236-6245

43. Kramer OH, Zhu P, Ostendorff HP, Golebiewski M, Tiefenbach J, Peters MA, Brill B, Groner B, Bach I, Heinzel T and Gottlicher M (2003) The histone deacetylase inhibitor valproic acid selectively induces proteasomal degradation of HDAC2. EMBO J. 22: 3411-3420

44. Zhang Y, LeRoy G, Seelig HP, Lane WS and Reinberg D (1998) The dermatomyositis-specific autoantigen Mi2 is a component of a complex containing histone deacetylase and nucleosome remodeling activities. Cell 95: 279-289

45. Bargonetti J and Manfredi JJ (2002) Multiple roles of the tumor suppressor p53. Curr. Opin. Oncol. 14: 86-91

46. el-Deiry WS (1998) Regulation of p53 downstream genes. Semin. Cancer Biol. 8: $345-357$ 
47. Lagger G, Doetzlhofer A, Schuettengruber B, Haidweger $E$, Simboeck $E$ Tischler J, Chiocca S, Suske G, Rotheneder H, Wintersberger E and Seiser C (2003) The tumor suppressor p53 and histone deacetylase 1 are antagonistic regulators of the cyclin-dependent kinase inhibitor p21/WAF1/CIP1 gene. Mol. Cell. Biol. 23: 2669-2679

48. Bartek $J$ and Lukas $J$ (2001) Pathways governing G1/S transition and their response to DNA damage. FEBS Lett. 490: 117-122

49. Choi YH, Lee WH, Park KY and Zhang L (2000) p53-independent induction of p21 (WAF1/CIP1), reduction of cyclin B1 and G2/M arrest by the isoflavone genistein in human prostate carcinoma cells. Jpn. J. Cancer Res. 91: 164-173

50. Hirose T, Sowa Y, Takahashi S, Saito S, Yasuda C, Shindo N, Furuichi K and Sakai T (2003) p53-independent induction of Gadd45 by histone deacetylase inhibitor: coordinate regulation by transcription factors Oct-1 and NF-Y. Oncogene 22: 7762-7773

51. Lavelle D, DeSimone J, Hankewych M, Kousnetzova T and Chen YH (2003) Decitabine induces cell cycle arrest at the G1 phase via p21(WAF1) and the G2/M phase via the p38 MAP kinase pathway. Leuk. Res. 27: 999-1007
52. Terui T, Murakami K, Takimoto R, Takahashi M, Takada K, Murakami T, Minami S, Matsunaga T, Takayama T, Kato J and Niitsu Y (2003) Induction of PIG3 and NOXA through acetylation of p53 at 320 and 373 lysine residues as a mechanism for apoptotic cell death by histone deacetylase inhibitors. Cancer Res. 63: 8948-8954

53. Yang XJ (2004) Lysine acetylation and the bromodomain: a new partnership for signaling. Bioessays 26: 1076-1087

54. Lennox RW and Cohen LH (1989) Analysis of histone subtypes and their modified forms by polyacrylamide gel electrophoresis. Methods Enzymol. 170: $532-549$

55. Thiriet $C$ and Albert $P$ (1995) Rapid and effective western blotting of histones from acid-urea-Triton and sodium dodecyl sulfate polyacrylamide gels: two different approaches depending on the subsequent qualitative or quantitative analysis. Electrophoresis 16: 357-361

56. Yang J, Liu X, Bhalla K, Kim CN, Ibrado AM, Cai J, Peng TI, Jones DP and Wang X (1997) Prevention of apoptosis by Bcl-2: release of cytochrome $c$ from mitochondria blocked. Science 275: 1129-1132 